\title{
NORTHERNMOST OCCURRENCE OF THE OFFSHORE ROCKFISH, PONTINUS KUHLII (SCORPAENIFORMES: SCORPAENIDAE), IN THE MEDITERRANEAN SEA
}

\author{
Antonio PAIS ${ }^{1 *}$, Lorenzo A. CHESSA ${ }^{1}$, Gavino DELRIO ${ }^{2}$ \\ ${ }^{1}$ Sezione di Acquacoltura ed Ecologia Marina, Dipartimento di Scienze Zootecniche, \\ ${ }^{2}$ Dipartimento di Protezione delle Piante; \\ Università di Sassari, Sassari, Italy
}

Pais A., Chessa L.A., Delrio G. 2005 Northernmost occurrence of the offshore rockfish, Pontinus kuhlii, (Scorpaeniformes: Scorpaenidae), in the Mediterranean Sea. Acta Ichthyol. Piscat. 35 (2): 143-145.

\begin{abstract}
An adult male specimen of the offshore rockfish, Pontinus kuhlii (Bowdich, 1825), was caught off the coast of Alghero (NW Sardinia, Italy) in August 2004. That capture represents the second documented record of this Atlantic migrant in Italian waters, after more than a century from the first report. Furthermore, the new specimen is the largest specimen of this species ever recorded in the Mediterranean Basin and the most northern capture for this geographic area. Morphologic and meristic characters of the collected fish are described and the existence of a Mediterranean population is hypothesized.
\end{abstract}

Key words: fish, zoogeography, offshore rockfish, Pontinus kuhlii, Scorpaenidae, Atlantic migrant, Mediterranean, Italy

According to Eschmeyer (1969), three species of the genus Pontinus Poey, 1860 (Scorpaeniformes, Scorpaenidae) occur in the eastern Atlantic: P. accraensis Norman, 1935, P. kuhlii (Bowdich, 1825), and P. leda Eschmeyer, 1969. The offshore rockfish, Pontinus kuhlii, is a bathydemersal species that commonly lives on hard bottoms at depths from 100 to 450 metres (Hureau and Litvineko 1986, Eschmeyer and Dempster 1990). It is a widely distributed eastern Atlantic fish and its geographic distribution extends from Madeira, the Azores, Portugal and the coast of Morocco to Mauritania and Cape Verde Island. Afonso et al. (1999) described a record from São Tomé Island (Gulf of Guinea) while another record was also reported from South Africa (Hureau and Litvineko 1986). In the Mediterranean Sea, Sauvage (1878) described Sebastes (Sebastichthys) bibroni as a new species on the basis of a single specimen (MNHN 7032) caught off the coast of Sicily, Italy. Subsequently, the species was synonymized with Scorpaena kuhlii (=Pontinus kuhlii). In the 20th century Massutí and Massó (1975) provided the second record of this scorpionfish for the Mediterranean Basin upon capturing a specimen (described by Tortonese 1979) at the Cabo de Palos Bank (Spain). Recently, Merella et al. (1998) reported another record of this species from Mallorca (Balearic Islands, Spain). Studies on the biology of Pontinus kuhlii and literature on the subject are scarce. Isidro (1990) and Monteiro et al. (1991) reported respectively on reproduc- tion and mercury contamination for fish collected in the Azores Archipelago. Krug et al. (1998) provided observa-

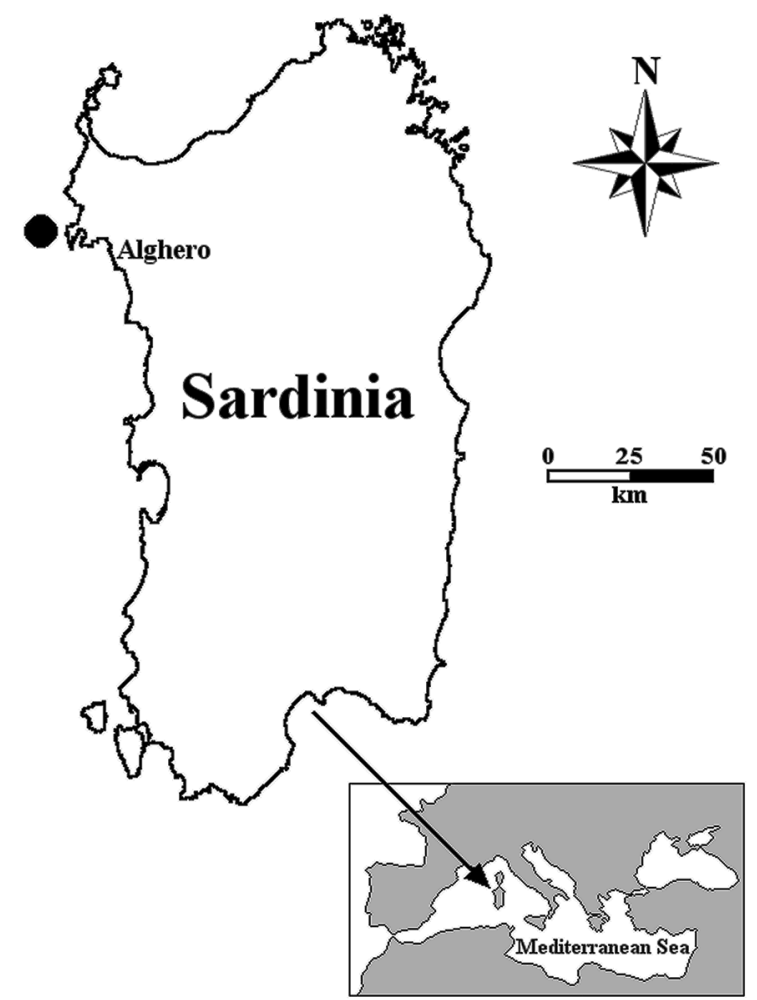

Fig. 1. Map showing where the herein reported specimen of Pontinus kuhlii was collected off Alghero, Sardinia, Italy

\footnotetext{
* Correspondence: Dr Antonio Pais, Sezione di Acquacoltura ed Ecologia Marina, Dipartimento di Scienze Zootecniche, Università di Sassari, Via E. De Nicola 9, 07100 Sassari, Italy, phone.: (+39) 079 229345, fax: (+39) 079 229302, e-mail: pais@uniss.it
} 


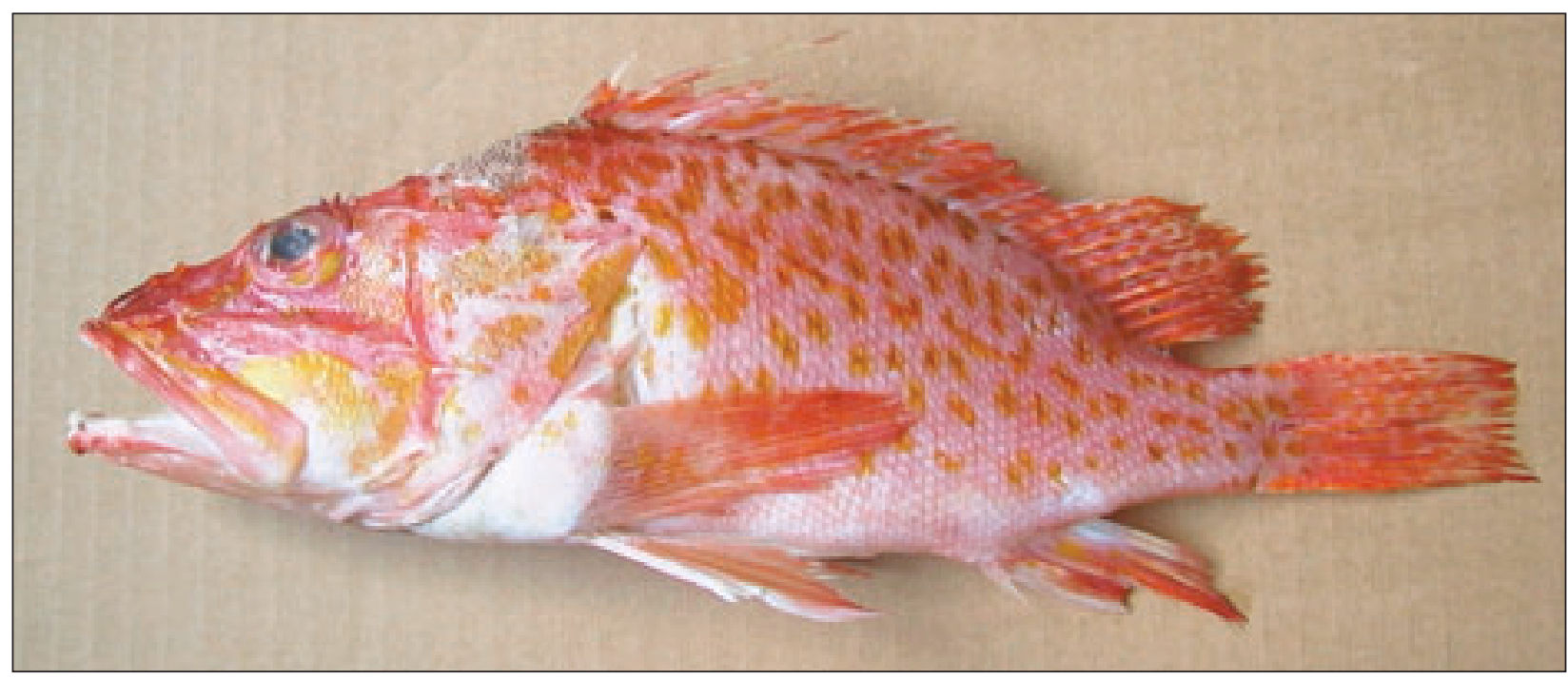

Fig. 2. Pontinus kuhlii (Bowdich, 1825). Department of Animal Science, University of Sassari (Italy) ichthyological collection (ref. number DSZ-11/04)

Table 1

Morphometric and meristic data for Pontinus kuhlii specimen collected off the coast of Alghero; the Roman and Arabic numbers reported for dorsal, anal, and ventral fins indicate spines and soft rays, respectively

\begin{tabular}{lcc}
\hline Morphometric characters & mm & $\begin{array}{l}\text { \% of } \\
\text { standard } \\
\text { length }\end{array}$ \\
\hline Total length & 344 & - \\
Standard length & 281 & - \\
Predorsal length & 108 & 38.4 \\
Prepectoral length & 122 & 43.4 \\
Preventral length & 111 & 39.5 \\
Preanal length & 207 & 73.7 \\
Head length & 127 & 45.2 \\
Eye diameter & 24 & 8.5 \\
Snout length & 44 & 15.7 \\
Interorbital width & 12 & 4.3 \\
Body height & 97 & 34.5 \\
Body width & 52 & 18.5 \\
Caudal peduncle length & 33 & 11.7 \\
Caudal peduncle height & 32 & 11.4 \\
Dorsal fin base length & 152 & 54.1 \\
Spinous dorsal fin base length & 104 & 37.0 \\
Soft dorsal fin base length & 51 & 18.1 \\
Pectoral fin length & 65 & 23.1 \\
Pelvic fin length & 74 & 26.3 \\
\hline Meristic features & & \\
\hline Dorsal fin & XII-10 & \\
Anal fin & 17 & \\
Pectoral fin & 25 & \\
Ventral fin & & \\
Branchiostegal rays & & \\
Gill-rakers on first arch & 5 & \\
Tubular scales in lateral line & & \\
\hline
\end{tabular}

tions on age and growth for P. kuhlii from the same geographic area, while López Abellán et al. (2001) studied the species age and growth from the Canary Islands Archipelago.

On 27 August 2004 an adult specimen of Pontinus kuhlii was caught by trammel net off the north-western coast of Alghero (Sardinia, Italy, 40³3'29'’N; $\left.8^{\circ} 19^{\prime} 20^{\prime \prime} \mathrm{E}\right)$ on a rocky bottom at a depth of about 120 meters (Fig. 1). This fishing ground is commonly called "Secca Garofalo". The fish (Fig. 2) was immediately frozen by the fisherman who caught it and subsequently identified using information in Eschmeyer (1969). The identification was based on the small scales (more than about 60 vertical scale rows) and elongate second and third dorsal spines. Afterwards the specimen was weighed and morphometric and meristic data were gathered (Table 1) following methods described by Strauss and Bond (1990). The specimen was then deposited in the ichthyological collection of the Department of Animal Science, University of Sassari, Italy (registration code DSZ-11/04).

The specimen was $34.4 \mathrm{~cm}$ long (total length) and it weighed $606.5 \mathrm{~g}$. The stomach was empty and the testicles spent. Hereafter follows a brief description of the fish examined. Body relatively compressed, head moderately large with well developed eyes in high position, and spines on top of head well developed. Two spines on pre-orbital and four on sub-orbital bone. Mouth large with pale rose-colored cavity. Second and third dorsal fin spines longer than others, all pectoral fin rays unbranched. Caudal fin with truncated posterior margin. Scales ctenoid, 64 vertical rows of lateral scales, lateral line with 26 tubular scales. Swimbladder present. Body colour reddish, darker dorsally than ventrally. Yellow areas on maxillary, sub-orbital region, preoperculum and operculum. Numerous yellow spots on body sides, small red spots on soft part of dorsal fin and also on caudal fin. Dark blotches at base of dorsal spines and on occipital region. Ventral area (from isthmus to anal fin) whitish to rose, without spots. White peritoneum.

This is the fourth documented record of this migrant from the Atlantic Ocean in the Mediterranean Sea and, after more than a century from the first, the second capture 
in Italian waters. It is the largest specimen of this species recorded in the Mediterranean Basin and the most northern capture for this region. Using the age-length relationship reported for this fish by López Abellán et al. (2001) from the Canary Islands, the newly reported specimen seems to have been between 9 and 15 years old. This new record of Pontinus kuhlii seems to confirm the hypothesis of Tortonese (1987) on the expanding range of this fish in the western Mediterranean Sea. According to Merella et al. (1998), the scarcity of records of this species may partly be due to its rarity but also, and above all, to the difficulty of collecting samples from waters with nontrawlable deep rocky bottoms.

\section{ACKNOWLEDGEMENTS}

The authors wish to express their gratitude to Giuseppe Delrio, skipper of the F/V ETNA of Alghero, for providing the specimen and for his active collaboration. Many thanks are also due to William N. Eschmeyer, Paolo Merella, Hiroyuki Motomura, and two anonymous reviewers for providing useful suggestions to improve the manuscript.

\section{REFERENCES}

Afonso P., Porteiro F.M., Santos R.S., Barreiros J.P., Worms J., Wirtz P. 1999. Coastal marine fishes of São Tomé Island (Gulf of Guinea). Arquipélago, Life and Marine Sciences (17A): 65-92.

Eschmeyer W.N. 1969. A systematic review of the scorpionfishes of the Atlantic Ocean (Pisces: Scorpaenidae). Occasional Papers of the California Academy of Sciences 79: 1-130.

Eschmeyer W.N., Dempster L.J. 1990. Scorpaenidae. pp. 665-679. In: Quero J.C., Hureau J.C., Karrer C., Post A., Saldanha L. (eds.) Check-list of the fishes of the eastern tropical Atlantic. Vol. 2. UNESCO, Paris.

Hureau J.C., Litvineko N.I. 1986. Scorpaenidae. pp. 1211-1229. In: Whitehead P.J.P., Bauchot M.L., Hureau J.C., Nielsen J., Tortonese E. (eds.) Fishes of the North-eastern Atlantic and the Mediterranean. Vol. III. UNESCO, Paris.

Isidro E.J. 1990. Reproduction and population biology of two commercial rockfish species from the Azores (Helicolenus dactylopterus and Pontinus kuhlii). Abstract of the First Congress on Oceanography and Marine Resources in the Central-East Atlantic: 27b.

Krug H., Rosa D., Menezes G., Pinho M. 1998. Age and growth of some demersal species of the Azores. ICES Doc CM, 1998/O: 84.

López Abellán L.J., Santamaría M.T.G., Conesa P. 2001. Age and growth of Pontinus kuhlii (Bowdich, 1825) in the Canary Islands. Scientia Marina 65 (4): 259-267.

Massutí M., Massó C. 1975. La pesca selectíva en el talud continental. Bancos de pesca I: el banco de Capo palos. Boletín del Instituto Español de Oceanografía 183: 1-26.

Merella P., Alemany F., Grau A. 1998. New data on the occurrence of Pontinus kuhlii (Bowdich, 1825) (Osteichthyes: Scorpaenidae) in the Western Mediterranean. Scientia Marina 62 (1-2): 177-179.

Monteiro L.R., Isidro E.J., Lopes H.D. 1991. Mercury content in relation to sex, size, age and growth in two scorpionfish (Helicolenus dactylopterus and Pontinus kuhlii) from Azorean waters. Water, Air, and Soil Pollution 56: 359-367.

Sauvage H.E. 1878. Description de poissons nouveaux ou imparfaitement connus de la collection du Muséum d'Histoire Naturelle; famille de scorpénidés, des platycéphalidés et des triglidés. Nouvelles Archives. Muséum National d'Histoire Naturelle, Series 2, 1: 109-158.

Strauss R.E., Bond C.E. 1990. Taxonomic methods: morphology. pp. 109-140. In: Schreck C.B., Moyle P.B. (eds.) Methods for fish biology. American Fisheries Society, Bethesda.

Tortonese E. 1979. Nota sobre la presenza di Pontinus kuhlii (Bowd.) in Mediterraneo ("Pisces Scorpaenidae"). Boletín del Instituto Español de Oceanografía 5: 4-6.

Tortonese E. 1987. Pesci del Mediterraneo. Recenti studi intorno alla sistematica e distribuzione. Quaderni dell'Istituto di Idrobiologia e Acquacoltura “G. Brunelli”. Il Ventaglio, Roma.

Received: 21 November 2005 Accepted: 15 December 2005 